University of South Carolina

Scholar Commons

Spring 2014

\title{
Hydraulic Fracturing on Federal and Indian Lands: An Analysis of the Bureau of Land Management's Revised Proposed Rule
}

\author{
Nathan D. Richardson \\ University of South Carolina - Columbia, richarnd@law.sc.edu \\ Alan Krupnick \\ Madeline Gottlieb \\ Molly Feiden
}

Follow this and additional works at: https://scholarcommons.sc.edu/law_facpub

Part of the Law Commons

\footnotetext{
Recommended Citation

Molly Feiden, Madeline Gottlieb, Alan Krupnick, Nathan RichardsonHydraulic Fracturing on Federal and Indian Lands: An Analysis of the Bureau of Land Management's Revised Proposed Rule, 29 J. Land Use \& Envtl. L. 337 (2013-2014)

This Article is brought to you by the Law School at Scholar Commons. It has been accepted for inclusion in Faculty Publications by an authorized administrator of Scholar Commons. For more information, please contact digres@mailbox.sc.edu.
} 


\title{
HYDRAULIC FRACTURING ON FEDERAL AND INDIAN \\ LANDS: AN ANALYSIS OF THE BUREAU OF LAND MANAGEMENT'S REVISED PROPOSED RULE
}

\author{
Molly Feiden, ${ }^{*}$ Madeline Gottlieb, ${ }^{* *}$ Alan Krupnick, ${ }^{* * *}$ \\ and Nathan Richardson ${ }^{* \star * *}$
}

\begin{abstract}
The federal government controls 700 million acres of subsurface rights (plus fifty-six million subsurface acres of Indian mineral estate) across twenty-four states, making it the largest landowner in the nation, and thus putting it in a position to negotiate lease terms and shape regulations of oil and gas development. The rules of the federal Bureau of Land Management (BLM) on how drilling activity can take place on federal lands essentially dictate terms, making BLM the largest "regulator" of drilling activity in the country. BLM last revised its oil and gas regulations (the Onshore Orders) in the 1980 s and early 1990 s, well before the recent rapid expansion of shale gas development. To date, there have been two rounds of proposed revisions, the first issued in 2012 and the most recent issued in May 2013, after BLM received 177,000 comments on the first round. This paper examines the 2013 proposal in several key respects, including the scope and requirements of the new proposal, the substantial changes from the 2012 proposal, and a comparison of BLM's proposed rules with rules in states with shale gas development and significant federal landholdings, based on earlier work. We find that BLM's proposal addresses some apparent gaps in state-level regulation and that, generally, BLM rules do not appear to impose significant requirements beyond existing state regulations, at least across the regulatory elements we analyzed and in those states with large federal landholdings.
\end{abstract}

* Molly Feiden is a research intern at Resources for the Future.

** Madeline Gottlieb is a senior research assistant at Resources for the Future.

*** Alan Krupnick is a RFF senior fellow and director of Resources for the Future's Center for Energy Economics and Policy; krupnick@rff.org.

**** Nathan Richardson is a resident scholar at Resources for the Future; richardson@rff.org. 


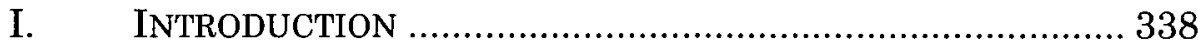

II. BLM's Role IN SHALE DEVELOPMENT

ON FEDERAL LANDS ..................................................... 339

III. THE 2013 BLM PROPOSAL ................................................ 341

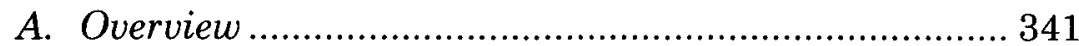

B. Changes from the 2012 Proposal.............................. 342

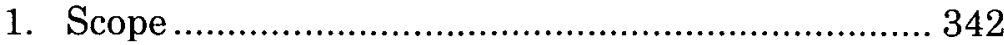

2. Frack Fluid Disclosure ....................................... 343

3. Testing Requirements for Casing and

Cementing (CELs/CBLs) .................................... 346

IV. The BLM PRoposal and State REgulation ................. 347

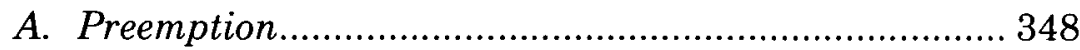

B. Areas of Concurrent State Regulation

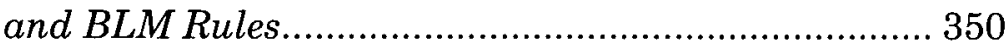

1. Setback Restrictions .......................................... 351

2. Casing and Cementing ....................................... 352

3. Casing and Cementing Testing............................ 353

4. Frack Fluid Disclosure ....................................... 354

5. Wastewater/Fluid Storage.................................... 355

6. Wastewater Transportation Tracking ................ 356

7. Accident Reporting ............................................... 357

8. Well Idle and Temporary Abandonment.............. 358

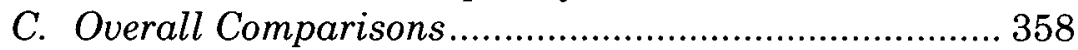

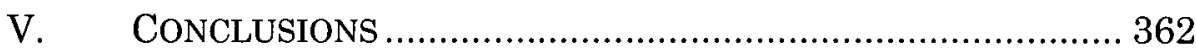

\section{INTRODUCTION}

The combination of horizontal drilling, hydraulic fracturing, and other technologies has led to a boom in development of oil and gas resources from shale rock previously considered inaccessible, dramatically increasing U.S. hydrocarbon production and opening many areas to significant new drilling activity. This activity is not without environmental, community, and other risks.

Traditionally, state governments have been viewed as the primary regulators of oil and gas development, with the federal government in a secondary role. But it is landowners, not the government, that create the first and, in some cases, strongest limits on developer activity through the restrictions they impose in lease terms. This power is particularly strong for large, institutional landowners. And it is strongest for the federal government, by far the largest landholder in the country. The Federal Bureau of Land Management (BLM) sets the lease terms for oil and gas develop- 
ment on 700 million subsurface acres of federal mineral estate. ${ }^{1}$ This is similar to (and is often called) a form of regulation but is better characterized as stewardship of land held in the public trust.

BLM also regulates fifty-six million subsurface acres of Indian mineral estate, but the actual leasing is left to the tribes. ${ }^{2}$ BLM has long regulated oil and gas development on federal and Indian lands through its onshore oil and gas operating regulations (Onshore Orders), ${ }^{3}$ most of which were last revised in the 1980 s or early 1990s. The recent expansion of shale gas development has led BLM to propose revisions specifically aimed at hydraulic fracturing activity to its rules. The agency issued a proposed set of rules in May $2012^{4}$ (the 2012 proposal) and recently issued a revised proposed rule $^{5}$ (the 2013 proposal) after receiving 177,000 comments.

This paper examines the 2013 proposal in several key respects. First, we consider the scope and requirements of the new proposal. Then we identify substantial changes from the 2012 proposal. Finally, we compare BLM's proposed rules with those already in place in states with shale gas development and significant federal landholdings, based on earlier work analyzing state-level rules. ${ }^{6}$

\section{BLM'S ROLE IN SHALE DEVELOPMENT ON FEDERAL LANDS}

BLM is the administrator of federal and (to a debatable extent) Indian lands, which are held in trust for the American people or for Indian tribes. BLM has the authority to lease federally owned

1. BLM's authority to lease federal mineral estate arises from the Mineral Leasing Act of 1920 and the Mineral Leasing Act for Acquired Lands of 1947. Mineral Leasing Act of 1920, 30 U.S.C. $§ 181$ (2012); Mineral Leasing Act for Acquired Lands of 1947, 30 U.S.C. $\S$ 351 et seq. (2012).

2. Under the Federal Land Policy and Management Act of 1976, Congress charged BLM with regulating oil and gas development and other activities on public lands for multiple use and sustained yield. Federal Land Policy and Management Act of 1976, 43 U.S.C. $\S \S$ 1701-1782 (1976). BLM has interpreted "public lands" to include Indian lands, although there is some debate as to whether that was Congress's intent.

3. Onshore Oil and Gas Orders/Notices to Lessees, BuREAU of LAND MGMT., http://blm.gov/wo/st/en/prog/energy/oil_and_gas/onshore_oil_and_gas.html (last updated June 5, 2012).

4. Oil and Gas; Well Stimulation, Including Hydraulic Fracturing, on Federal and Indian Lands, 77 Fed. Reg. 27,691 (May 11, 2012) (to be codified at 43 C.F.R. $\$ 3160$ ).

5. Oil and Gas; Hydraulic Fracturing on Federal and Indian Lands, 78 Fed. Reg. 31,636 (May 24, 2013) (to be codified at 43 C.F.R. $\$ 3160$ ), available at http://blm.gov/ pgdata/etc/medialib/blm/wo/Communications_Directorate/public_affairs/hydraulicfracturing .Par.91723.File.tmp/HydFrac_SupProposal.pdf.

6. Nathan Richardson, Madeline Gottlieb, Alan Krupnick \& Hannah Wiseman, The State of State Shale Gas Regulation, RESOURCES FOR THE FUTURE, June 2013, available at http://www.rff.org/rff/documents/RFF-Rpt-StateofStateRegs_Report.pdf. 
(non-Indian) mineral estate, which lies below more than 700 million acres of federal, state, and private land, mostly in western states. ${ }^{7}$ BLM has issued such leases since 1988 under the current law, the Federal Onshore Oil and Gas Leasing Reform Act of 1987,8 and production from federal onshore wells currently accounts for roughly eleven percent of the country's natural gas supply and five percent of its oil supply. ${ }^{9}$

Pursuant to BLM authority granted in its operating regulations, ${ }^{10} \mathrm{BLM}$ has issued seven Onshore Orders that implement and supplement the operating regulations. The Onshore Orders apply to all oil and gas development on federal and Indian lands, and thus operators developing shale gas on these lands must comply with these rules. The seven Onshore Orders were created between 1983 and 1993 and only one has since been revised. ${ }^{11}$ In addition to the Onshore Orders, which apply to all types of oil and gas development, the operating regulations contain a short provision that is specific to hydraulic fracturing and a few other activities. ${ }^{12}$ That rule was created in 1982 and has not been revised since 1988 .

Since the mid-1970s, hydraulic fracturing (commonly referred to as fracking) - a process where water, sand, and other chemicals are injected into the wellbore at high pressure to create fractures and stimulate production - has been commonly used on vertical gas wells. However, it was not until the 2000 s that combining hydraulic fracturing and horizontal drilling became widespread as a technique to make the production of oil and gas from shale economically feasible. ${ }^{13}$ According to BLM, the expansion of shale gas

7. Note that the federal government may own (and BLM may therefore administer) mineral rights under land (surface rights) not owned by the federal government. This is termed a "split estate."

8. The Mineral Leasing Act of 1920 was amended by the Federal Onshore Oil and Gas Leasing Reform Act of 1987, which leaves BLM to administer leasing but gives the Forest Service a more direct role in the leasing process for lands under its jurisdiction. The amendment also established that all public land leasing must be open to competitive leasing. 30 U.S.C. $\$ 181(2012)$.

9. Oil and Gas, BUREAU OF LAND MGMT., http://blm.gov/wo/st/en/prog/energy/oil_ and_gas.html last updated June 20, 2014).

10. 43 C.F.R. $\$ 3164.1$ (2007). Onshore oil and gas operating regulations authorize BLM's director to issue Onshore Oil and Gas Orders when necessary to implement and supplement the operating regulations.

11. Onshore Order Number 1, Approval of Operations, which provides procedures for submitting an Application for Permit to Drill and other required approvals, was updated in 2007. 43 C.F.R. $\$ 3160$ (2007).

12. 43 C.F.R. $\$ 3162.3-2$ (1988).

13. The percentage of total U.S. natural gas production accounted for by shale gas grew from 1.6 percent in 2000 to 23.1 percent by 2010. Zhongmin Wang \& Alan Krupnick, U.S. Shale Gas Development: What Led to the Boom?, RESOURCES FOR THE FUTURE, MAY 2013, available at http://rff.org/RFF/Documents/RFF-IB-13-04.pdf. 
development has created a need to update existing rules embodied in the Onshore Orders. ${ }^{14}$

BLM's recent proposals can be characterized as a set of new rules that will (when and if finalized) apply to fracking and some related activity on those lands within the bureau's jurisdictionthe first substantial revision of such rules since 1993 and the first to apply specifically to fracking.

\section{THE 2013 BLM PROPOSAL}

The 2013 proposal includes a wide range of requirements spanning the development process but focuses on frack fluid disclosure and testing requirements for casing and cementing. Other sections of the 2013 proposal create new requirements for mapping of fracture propagation and wastewater fluid storage. For several other activities, the 2013 proposal defers to the Onshore Orders issued by BLM more than 20 years ago.

\section{A. Overview}

- Frack fluid disclosure: Operators would be required to submit chemical information on FracFocus, ${ }^{15}$ directly to BLM, or to another BLM-approved database after fracking is completed. ${ }^{16}$ Operators will be able to avoid disclosure of compounds they claim are trade secrets in an affidavit, without submitting any chemical information to BLM. ${ }^{17}$

- Testing requirements for casing and cementing:

- Cement evaluation logs: Operators would be required to compile cement evaluation logs (CELs) and make them available to BLM. ${ }^{18}$ These logs record the results of tests used to detect areas where casing is not

14. See Oil and Gas; Hydraulic Fracturing on Federal and Indian Lands, 78 Fed. Reg. 31,636 .

15. FracFocus is an Internet database for industry's voluntary reporting of chemicals used in hydraulic fracturing, as well as a tool for the public and others to use to query this database. See FRACFOCUS CHEM. DISCLOSURE REGISTRY, http://www.fracfocus.org (last visited June 30, 2014).

16. Oil and Gas; Hydraulic Fracturing on Federal and Indian Lands, 78 Fed. Reg. $31,636,31,636$ (proposed May 24, 2013) (to be codified at 43 C.F.R. pt. 3160.3-3(i)).

17. Oil and Gas; Hydraulic Fracturing on Federal and Indian Lands, 78 Fed. Reg. 31,636, 31,659 (proposed May 24, 2013) (to be codified at 43 C.F.R. pt. 3162.3-3(j)(1)-(4)).

18. Oil and Gas; Hydraulic Fracturing on Federal and Indian Lands, 78 Fed. Reg. 31,636, 31,641 (proposed May 24, 2013) (to be codified at 43 C.F.R. pt. 3162.3-3(d)(2)). 
bound to cement, which creates a risk of fluids inside the wellbore migrating into water aquifers.

- Mechanical integrity testing: In addition to maintaining CELs, operators would be required to run mechanical integrity tests (MIT) on the vertical sections of the casing prior to fracking or refracking to ensure that the casing can withstand fracking pressures, and continue to monitor pressures during fracking. ${ }^{19}$

- Fracture propagation monitoring: Operators would be required to create maps plotting estimated fracture propagation (how cracks in the rock would spread as a result of fracking), along with fracture direction, length, and height, to ensure that fracking does not threaten aquifers or other resources. ${ }^{20}$

- Wastewater fluid storage: Operators would be required to use (at a minimum) lined pits to store flow back fluid and other wastewater, and BLM would reserve the authority to require operators to take other protective measures.

\section{B. Changes from the 2012 Proposal}

The 2013 proposed rule is less stringent than the 2012 proposal in two major regulatory areas: frack fluid disclosure and testing well cementing and casing. This is in addition to the other major change discussed above, narrowing the scope of the rule to apply only to shale gas development where hydraulic fracturing is used.

\section{Scope}

In its 2012 proposal, BLM would have imposed new rules on all "well stimulation" activities, including not only hydraulic fracturing but also other activities that increase the permeability of reservoir rock, such as acidizing, flooding, and tertiary recovery

19. Oil and Gas; Hydraulic Fracturing on Federal and Indian Lands, 78 Fed. Reg. 31,636, 31,676 (proposed May 24, 2013) (to be codified at 43 C.F.R. pt. 3162.3-3 (f)-(g)).

20. Oil and Gas; Hydraulic Fracturing on Federal and Indian Land, 78 Fed. Reg. 31,636, 31,648-49 (proposed May 24, 2013) (to be codified at 43 C.F.R. pt. 3162.3-3(d)(4)(iv)). 
through steam injection. ${ }^{21}$ However, BLM narrowed the scope of its 2013 proposal such that it would apply only to "hydraulic fracturing" and "refracturing." 22

"According to BLM, the change was made in response to industry comments that inclusion of well stimulation activities would make the rule too onerous for what they consider routine maintenance operations." 23 However, some of these activities, such as "acidizing" a well by pumping in large amounts of acid to dissolve rock formations and stimulate production, are often used in conjunction with fracking and may involve risk factors similar to those associated with fracking. ${ }^{24}$

\section{Frack Fluid Disclosure}

The 2013 proposal kept in place the 2012 proposal's requirement that fracking chemicals be disclosed after fracking has been completed. ${ }^{25}$ However, the 2013 proposal revises the nature of the chemical disclosure requirements in three ways. These changes generally reduce burdens on operators, at the cost of some transparency.

First, the 2013 proposal eliminates a requirement that operators provide the estimated chemical composition of flowback fluids before fracking operations begin, as part of the approval process. ${ }^{26}$ BLM defended this revision on the grounds that the estimations could be unreliable given that operators are permitted to change the chemical composition of frack fluids after approval to begin operations. ${ }^{27}$

21. Oil and Gas; Well Stimulation, Including Hydraulic Fracturing, on Federal and Indian Lands, 77 Fed. Reg. 27,691, 27,695 (proposed May 11, 2012) (to be codified at 43 C.F.R. pt. 3160-5).

22. Oil and Gas; Hydraulic Fracturing on Federal and Indian Lands, 78 Fed. Reg. 31,636, 31,647 (proposed May 24, 2013) (to be codified at 43 C.F.R. pt. 3160.0-5).

23. Oil and Gas; Hydraulic Fracturing on Federal and Indian Lands, 78 Fed. Reg. 31,636, 31,645 (proposed May 24, 2013) (to be codified at 43 C.F.R. pt. 3160.0-5).

24. See generally, LEONARD Kalfayan, PRODUCTION ENHANCEMENT WITH ACID STIMULATION (PennWell Books, 2nd ed. 2008); see also ARMSTRONG AGBAJI ET AL., REPORT ON Sustainable Development and DEsign of MaRCEllus Shale Play In SusquehanNa, PA 7 (2009), available at http://energy.wilkes.edu/PDFFiles/Library/Sustainable\%20Develop ment\%20of\%20Marcellus\%20Shale\%20in\%20Susquehanna.pdf.

25. Oil and Gas; Hydraulic Fracturing on Federal and Indian Lands, 78 Fed. Reg. 31,636, 31,636 (proposed May 24, 2013) (to be codified at 43 C.F.R. pt. 31,63-3(i)).

26. Compare Oil and Gas; Well Stimulation, Including Hydraulic Fracturing, on Fed. eral and Indian Lands, 77 Fed. Reg. 27,691, 27,696 (proposed May 11, 2012) (to be codified at 43 C.F.R. pt. 3162.3-3(c)(6)), with Oil and Gas; Hydraulic Fracturing on Federal and Indian Lands, 78 Fed. Reg. 31,636, 31,649 (proposed May 24, 2013) (to be codified at 43 C.F.R. pt. 3162.3-3(d)(5)).

27. Oil and Gas; Hydraulic Fracturing on Federal and Indian Lands, 78 Fed. Reg. 31,636-01, 31,649 (proposed May 24, 2013) (to be codified at 43 C.F.R. pt. 3160). 
BLM also noted that requiring the estimations might result in public discovery of chemical constituents of the fluids prior to operations ${ }^{28}$ - some of which might be protected trade secrets. Because the actual chemical composition of frack fluids is reported after fracking takes place rather than as part of the approval process, the 2012 proposal's requirement of advance estimates of flowback fluid composition was the only data related to frack fluids submitted as part of BLM's drilling approval process. Under the 2013 proposal, therefore, no predrilling information on frack fluids is submitted to BLM.

Second, the 2013 proposal changed format and procedural requirements for reporting frack fluids after fracking is completed. ${ }^{29}$ Frack fluid disclosure to BLM is, under the 2013 proposal, explicitly modeled after the fracking disclosure website, FracFocus. Although reporting directly to BLM or another database specified by BLM would still be permitted, FracFocus will presumably become the preferred, if not the exclusive, choice of operators fulfilling BLM regulations.

Use of FracFocus to comply with the new BLM regulations raises some concerns. A recent Harvard study claims that "reliance on the FracFocus registry as a regulatory compliance tool is misplaced or premature." 30 The study finds that FracFocus encourages inaccurate reporting, lacks a review process for submissions, and leaves regulators unable to enforce reporting deadlines. ${ }^{31}$ FracFocus has undergone significant changes since this study was released, however, with version 2.0 of the website deployed on June $1,20133^{32}$

These upgrades may have addressed some of the concerns raised by the Harvard study. The FracFocus website notes that the upgrades "will dramatically improve the site's functionality for state regulatory agencies, industry, and public users." ${ }^{33}$ Specifically, users will be able to locate well site chemical information,

28. Id.

29. Compare Oil and Gas; Well Stimulation, Including Hydraulic Fracturing, on Federal and Indian Lands, 77 Fed. Reg. 27,691, 27,698 (proposed May 11, 2012) (to be codified at 43 C.F.R. pt. $3162.3-3(\mathrm{~g})(2)$, (4), (5)), with Oil and Gas; Hydraulic Fracturing on Federal and Indian Lands 78 Fed. Reg. 31,636, 31,656 (proposed May 24, 2013) (to be codified at 43 C.F.R. pt. 3162.3-3(i)(1)).

30. Kate Koschnick et al., Legal Fractures in Chemical Disclosure LaWs: Why the Voluntary Chemical Disclosure Registry FracFocus Fails as a Regulatory COMPLIANCE TOOL 1 (Harvard Envtl. Law Program, 2013), available at http://blogs.law. harvard.edu/environmentallawprogram/files/2013/04/4-23-2013-LEGAL-FRACTURES.pdf.

31. Id.

32. FracFocus ChEM. Disclosure REgistry, http://fracfocus.org (last visited June 30,2014$)$.

33. FracFocus 2.0 to Revolutionize Hydraulic Fracturing Chemical Reporting Nationwide, FracFocus Chem. Disclosure Registry (May 29, 2013), http://fracfocus.org/ node/347. 
chemical names, and Chemical Abstract Service (CAS) numbers more efficiently. ${ }^{34}$

Third and finally, the 2013 proposal also revises substantive rules for fluid disclosure, eliminating the 2012 proposal's requirement that operators submit chemical information to BLM in order to substantiate trade secret claims. ${ }^{35}$ This was replaced by a provision that instructs operators to submit affidavits that the information is subject to trade secret protection. ${ }^{36}$ The affidavits, which were modeled after those required by Colorado, must affirm the following:

- that the chemical information is not public;

- that the chemical information is not required to be made public;

- that the information is not easily discoverable through reverse engineering; and

- that its release would likely diminish the competitiveness of the company. ${ }^{37}$

BLM would retain discretion to require submission of nondisclosed chemical information for review ${ }^{38}$ and the provision suggests that discretion would be exercised in the event of incomplete affidavits. ${ }^{39}$ However, no information is provided as to how BLM will review the affidavits or the specific criteria that will be used to evaluate trade secret exemptions.

Whether operators' claims regarding trade secret protection (formalized in affidavits) are sufficiently reliable is not clear. Under the 2013 proposal, BLM will clearly have less information available to evaluate trade secret claims and, in practice, may not be able to do so.

34. Id.

35. Compare Oil and Gas; Well Stimulation, Including Hydraulic Fracturing, on Federal and Indian Lands, 77 Fed. Reg. 27,691, 27,711 (proposed May 11, 2012) (to be codified at 43 C.F.R. pt. 3162.3-3(h)-(i)), with Oil and Gas; Hydraulic Fracturing on Federal and Indian Lands, 78 Fed. Reg. 31,636, 31,677 (proposed May 24, 2013) (to be codified at 43 C.F.R. pt. 3162.3-3(j)(1)-(4)).

36. Oil and Gas; Hydraulic Fracturing on Federal and Indian Lands, 78 Fed. Reg. 31,636, 31,677 (proposed May 24, 2013) (to be codified at 43 C.F.R. pt. 3162.3-3(j)(1)).

37. Id.

38. Oil and Gas; Hydraulic Fracturing on Federal and Indian Lands, 78 Fed. Reg. 31,636, 31,659 (proposed May 24, 2013) (to be codified at 43 C.F.R. pt. 3162.3-3(j)(2)).

39. Oil and Gas; Hydraulic Fracturing on Federal and Indian Lands, 78 Fed. Reg. 31,636, 31,659 (proposed May 24, 2013) (to be codified at 43 C.F.R. pt. 3160). 


\section{Testing Requirements for Casing and Cementing (CELs/CBLs)}

A variety of tests are commonly used to detect areas where casing is not properly bound to cement. Such failures increase the risk of frack fluids, flowback water, or other materials in the wellbore migrating into water aquifers. The results of these tests are recorded in instruments referred to as cement evaluation logs (CEL) or cement bond logs (CBL). Both the 2012 and 2013 proposals require such tests and logs, but the 2013 proposal changed several aspects of the testing requirements. Notably, the 2013 requirements regarding when and under what circumstances casing and cementing must be tested would result in less agency overview of well integrity, especially during the approval process.

The 2012 proposal would have required testing on each well, ${ }^{40}$ while the 2013 proposal would allow operators to avoid testing well integrity where other wells with the same specifications and geologic parameters have been tested and have produced satisfactory results. ${ }^{41}$ According to BLM, this change was made because of its agreement with industry comments that testing on every well may be unnecessarily expensive, may induce unnecessary delay, and would not decrease the risk of contamination of water aquifers. ${ }^{42}$

Additionally, the 2012 proposal would have required submissions of test results to BLM during the approval process-before beginning fracking operations. ${ }^{43}$ In response to comments asserting that BLM's review of casing and cementing test results during the approval process would cause significant delay, the rule was revised to take submission of test results out of the approval process and instead require operators to submit the results after fracking operations are completed. ${ }^{44}$ The 2013 proposal does, however, add a requirement for operators to monitor and record the flow rate, density, and pumping pressure of the cementing and run

40. Oil and Gas; Well Stimulation, Including Hydraulic Fracturing, on Federal and Indian Lands, 77 Fed. Reg. 27,691, 27,710 (proposed May 11, 2012) (to be codified at 43 C.F.R. pt. 3162.3-3(c)(2)).

41. Oil and Gas; Hydraulic Fracturing on Federal and Indian Lands, 78 Fed. Reg. 31,636, 31,676 (proposed May 24, 2013) (to be codified at 43 C.F.R. pt. 3162.3-3(e)(3)).

42. Oil and Gas; Hydraulic Fracturing on Federal and Indian Lands, 78 Fed. Reg. 31,636, 31,652 (proposed May 24, 2013) (to be codified at 43 C.F.R. pt. 3160).

43. Oil and Gas; Well Stimulation, Including Hydraulic Fracturing, on Federal and Indian Lands, 77 Fed. Reg. 27,691, 27,710 (proposed May 11, 2012) (to be codified at 43 C.F.R. pt. 3162.3-3(c)(2)).

44. Oil and Gas; Hydraulic Fracturing on Federal and Indian Lands, 78 Fed. Reg. 31,636, 31,658, 31,675 (proposed May 24, 2013) (to be codified at 43 C.F.R. pt. 3162.3$3(\mathrm{e})(2))$. 
a cementing and casing test prior to operations in the event that monitoring indicates inadequate cementing. ${ }^{45}$

The 2013 proposal also adds more flexibility for operators in choosing which method to use in testing the well cementing and casing. The 2012 proposal would have required operators to create CBLs. ${ }^{46}$ Those logs comprise data generally gathered through a sonic technology that detects whether casing is bound to the cement based on the level of resonance of vibrations. ${ }^{47}$ The 2013 proposal uses the broader term CEL rather than CBL. ${ }^{48}$ CELs include a variety of additional methods for testing well cementing and casing. ${ }^{49}$ BLM may also allow another test required by a state or tribe so long as it is "at least as effective in assuring adequate cementing." 50 Whether these changes will affect BLM's ability to ensure proper casing and cementing is unclear.

\section{THE BLM PROPOSAL AND STATE REGULATION}

All western states with large shale gas reserves and significant federal landholdings regulate oil and gas development and have done so for decades. Within these regulations, many states have rules that apply specifically to unconventional development. State law generally does not apply on Indian lands, but many Indian lands also have their own laws regulating oil and gas development. Therefore, if BLM rules are different than state or tribal regulations, operators would appear to be left with two layers of regulation. In one sense, this is no different than on private lands, where operators must comply with state law as well as any restrictions imposed by the landowner via the lease or other agreement. Nevertheless, BLM rules may require operators on federal lands in many cases to interact with multiple layers of government (federal and state), and therefore function in many ways as concurrent regulations.

45. Oil and Gas; Hydraulic Fracturing on Federal and Indian Lands, 78 Fed. Reg. 31,636, 31,675 (proposed May 24, 2013) (to be codified at 43 C.F.R. pt. 3162.3-3(e)(1)).

46. Oil and Gas; Well Stimulation, Including Hydraulic Fracturing, on Federal and Indian Lands, 77 Fed. Reg. 27,691 (proposed May 11, 2012) (to be codified at 43 C.F.R. $3162.2-2(\mathrm{c})(2))$.

47. Oilfield Glossary, SCHLUMBERGER, http:/glossary.oilfield.slb.com/en/Terms.aspx? LookIn=term\%20name\&filter=cement\%20bond\%20log (last visited June 30, 2014).

48. Oil and Gas; Hydraulic Fracturing on Federal and Indian Land, 78 Fed. Reg. $31,636,31,651$ (proposed May 24, 2013) (to be codified at 43 C.F.R. $\S 3162.3-3(e)(2)$ ).

49. Id.

50. Id. 


\section{A. Preemption}

Do BLM rules preempt (i.e., displace) state law? Generally, no. The Supreme Court has recognized two ways that federal law can preempt state law. "Conflict preemption" occurs where a federal and state law directly conflict so that compliance with both is not possible. ${ }^{51}$ Even where federal and state laws do not directly conflict, state law may be "field preempted" where federal regulation in a certain area is so pervasive that it is clear, either by express language or by implication, that lawmakers intended for the federal government to occupy that entire field of regulation. ${ }^{52}$

BLM makes clear in the 2013 proposal that it does not intend to be the sole regulator of shale gas development on public lands (and thus will not field preempt) but rather intends to create a backstop regulation that will not preempt more stringent state laws. ${ }^{53}$ States are therefore free to impose additional requirements beyond those in BLM's rules, and existing state law that is more stringent is not affected by BLM rules.

Furthermore, the 2013 proposed rule adds a provision allowing states or tribes to apply for variances from the BLM rule for operational activities and technology standards, such as monitoring and testing. ${ }^{54}$ If BLM approves a variance on the grounds that it meets or exceeds the agency's standards, compliance with the specific state or tribal rule would satisfy the BLM rule.

BLM does not, however, address in the proposal the fact that there could be areas where the state rule is different from the BLM rule but not necessarily more or less stringent (and a variance is not applied for or granted). In those cases, where the two rules directly conflict so that an operator could not simultaneously comply with both, the BLM rule presumably would preempt the state rule. In this respect, BLM rules are different from those imposed by private landowners who obviously have no authority to alter state law requirements. Whether such conflicts actually might occur in prac-

51. See Gibbons v. Ogden, 22 U.S. 1 (1824).

52. See, e.g., Rice v. Santa Fe Elevator Corp., 331 U.S. 218 (1947).

53. BLM concluded that the rule would not require a Federalism Assessment under Executive Order 13132 because it "would not have a substantial direct effect on the States, on the relationship between the national government and the States, or on the distribution of power and responsibilities among the various levels of government." 78 Fed. Reg. 31,669. A Federalism Assessment includes identifying the additional costs and burdens on the states, such as the likely sources of funding and the ability of the states to fulfill the purposes of the policy and identifying the extent to which the policy affects the states' ability to discharge their traditional functions. Exec. Order No. 12,612, 52 Fed. Reg. 41,685 (Oct. 26, 1987).

54. Oil and Gas; Hydraulic Fracturing on Federal and Indian Lands, 78 Fed. Reg. $31,636,31,660-61$ (proposed May 24, 2013) (to be codified at 43 C.F.R. $\S 3162.3-3(\mathrm{k})$ ). 
tice is unclear, however. In our analysis of a selection of regulatory elements below, we have not identified any.

Preemption on Indian lands is a bit different, as the Constitution grants Congress full authority to control tribal affairs and limit their powers. Nonetheless, because of the long-existing policy of recognizing tribal autonomy, federal regulation of oil and gas development on Indian lands has been seen by some as overstepping boundaries of tribal sovereignty. ${ }^{55}$ In fact, some argue that BLM lacks statutory authority to regulate oil and gas on Indian lands at all because Congress excluded Indian lands in its definition of public lands under BLM jurisdiction. ${ }^{56}$

However, there is an apparent need for regulation of oil and gas development on Indian lands. Unlike state regulations, tribal laws governing oil and gas production are generally vague or nonexistent. For example, the legal code for the Blackfeet Indian Reservation in Montana requires approval by a board for "extraction" and "oil wells" but has no codified regulations for oil and gas drilling in general or for fracking in particular. ${ }^{57}$

The position of the tribes appears to be mixed. Some Native American advocates pushed for an opt-out provision for tribes with their own regulations, which BLM refused to include in either version of the proposed rule. ${ }^{58}$ Other tribes appear to support federal regulation. For example, Wind River Indian Reservation in Wyoming includes in its legal code a provision emphasizing the importance of compliance with various federal environmental acts and especially BLM's rules for onshore oil and gas development. ${ }^{59}$

Given the overlap between state (and tribal) regulations and BLM rules and the ability of states to regulate more stringently, the substantive significance of BLM's proposal in practice depends on the degree to which it imposes requirements beyond those under existing law. BLM rules will provide additional environmental protection only if they are more stringent than those imposed by states or restrict operator behavior in areas not addressed by state rules at all.

55. See Tom Fredericks \& Andrea Aseff, When Did Congress Deem Indian Lands Pub. lic Lands?: The Problem of BLM Exercising Oil and Gas Regulatory Jurisdiction in Indian Country, 33 ENERGY L.J. 119 (2012), available at http:/felj.org/sites/default/files/docs/elj331/ 14-119-fredericks_and_aseff-problem_of_blms_indian_country_oil_and_gas_jurisdiction.pdf.

56. Id.

57. BLACKFEET TRIBAL LAW \& ORDER CODE, Ch. 12, § 3.03, available at http://narf.org/ nill/Codes/blackfeetcode/blkftcode12land.htm.

58. See Mike Soraghan \& Ellen M. Gilmer, Revised Interior Rule Loops in IndustryFavored FracFocus, ENERGYWIRE (Feb. 8, 2013), available at http://eenews.net/stories/ 1059976058.

59. SHOSHONE \& ARAPAHO LAW \& ORDER CODE tit. X, available at http:/narf.org/nill/ Codes/shoshonearapaho/title_xi.pdf. 
It is important to note, however, that it is possible for BLM rules to impose additional procedural burdens even if they do not impose additional substantive requirements beyond those under existing state law. For example, BLM could require operators to undergo a separate permit process with identical (or weaker) standards than states or to submit documents in different formats than states require. Such procedural burdens should not be ignored-they impose costs on operators without any direct environmental or public health benefit.

\section{B. Areas of Concurrent State Regulation and BLM Rules}

In order to ascertain the extent to which BLM's 2013 proposal would require operators to take measures beyond those in current state laws, we look at regulations in six states with large percentages of federally owned mineral rights and potential shale gas development-California, Colorado, Montana, New Mexico, Utah, and Wyoming-and compare these regulations with the BLM rules. Most of the state-level data are drawn from our 2013 report, The State of State Shale Gas Regulation. ${ }^{60}$ That report detailed regulations in thirty-one states across twenty-five regulatory elements that span the shale gas development process. In comparing state rules with BLM's proposal, we look at eleven regulatory elements, ${ }^{61}$ excluding those that are generally regulated by another federal agency or are relevant only at the state level. ${ }^{62}$ For a few elements covered by BLM's rules, we provide additional detail on state regulations beyond that included in the report. The elements reviewed in this section include the following:

- building setback restrictions;

- water setback restrictions;

- casing and cementing restrictions;

- testing of casing and cementing, including mechanical integrity tests (MITs) and cement evaluation or bond logs (CELs or CBLS);

- wastewater storage options (pits or tanks);

- pit liner requirements;

60. See Richardson et al., supra note 6 .

61. In The State of State Shale Gas Regulation, readers will find four casing and cementing regulatory elements. In the discussions in this paper, these are aggregated into one category for convenience purposes. See Richardson et al., supra note 6.

62. For example, air quality regulation generally falls under EPA authority; BLM therefore did not regulate venting and flaring of gas in its proposal. Severance tax rates and the number of state-level regulatory agencies are also irrelevant to BLM's proposal. 
- wastewater transportation tracking;

- accident reporting;

- well idle time limits;

- temporary abandonment time limits; and

- frack fluid disclosure rules.

Even within these elements, there are limits on our ability to make meaningful comparisons between state and BLM rules. BLM may lack legal authority to regulate some elements fully. The agency might also regulate informally via its case-by-case approval process. More generally, we do not have data on enforcement or effectiveness of BLM or state regulations. This limits our ability to make any claims about relative or absolute quality of regulations in practice.

The following subsections discuss each regulatory element in both state regulations and BLM's rules, including the 2013 proposal. The next section presents a general and statistical comparison.

\section{Setback Restrictions}

BLM's 2013 and 2012 proposals do not impose setback restrictions, required minimum distances between wells, and other features believed to merit protection, such as buildings or water sources. Though setback restrictions from buildings and water are common in state regulations across the country, of the six western states we examine here, only half have such regulations. ${ }^{63}$

While there is no evidence to suggest that setback restrictions are outside BLM jurisdiction, the agency may have other reasons for leaving out setback restrictions. BLM land generally has far lower building density than non-BLM land, ${ }^{64}$ so setback rules might be less necessary. Where setback restrictions are beneficial, BLM might add them to its otherwise standard terms for oil and gas leases. ${ }^{65}$ For example, Wayne National Forest in Ohio requires analyses by the Forest Service to determine whether setback restrictions should be added to specific fracking leases for the purpose of protecting objects of historic or scientific interest, or sensi-

63. See Richardson et al, supra note 6 , at 25.

64. For example, in 2012, there were only 149 buildings on Wyoming BLM-managed federal lands, 678 buildings on California BLM lands, 215 buildings on New Mexico BLM lands, and 18 buildings on BLM lands in all of the eastern states combined. See U.S. DEP'T OF THE INTERIOR, BUREAU OF LAND MGMT., PUBLIC LAND STATISTICS 250 (2012), available at http://blm.gov/public_land_statistics/pls12/pls2012.pdf.

65. A standardized BLM oil and gas lease form can be found online at Offer To Lease And Lease Oil And Gas, U.S. DEP'T OF THE INTERIOR, BUREAU OF LAND MGMT., available at http://blm.gov/pgdata/etc/medialib/blm/noc/business/eforms.Par.71287. File.dat/3100-011.pdf. 
tive habitat and wildlife. ${ }^{66}$ Deciding whether and to what extent to include setbacks based on conditions at the lease site is akin to case-by-case permitting.

\section{Casing and Cementing}

The 2013 proposal defaults to Onshore Order No. $2^{67}$ for casing and cementing rules. ${ }^{68}$ According to Onshore Order No. 2, casing and cementing programs "shall be conducted as approved to protect and/or isolate all usable water zones, lost circulation zones, abnormally pressured zones, and any prospectively valuable deposits of minerals." 69 In addition, casing depth is to be determined based on "all relevant factors," including the presence or absence of hydrocarbons, fracture gradients, usable water zones, formation pressures, lost circulation zones, and other minerals. ${ }^{70}$ No specific requirements are given. We classify this type of regulation as a performance standard.

In contrast, all six western states regulate casing and cementing depth with command-and-control regulations. ${ }^{71}$ Regulations in four of the states impose requirements on cement composition. ${ }^{72}$ All six states also regulate cement circulation: all require surface casing to be cemented fully to the surface, and four of the six impose requirements on circulation in intermediate and production casing as well. ${ }^{73}$

While the casing and cementing rules in Onshore Order No. 2 provide a large amount of flexibility, they are inherently less transparent because of the lack of specific standards. BLM's performance standards are therefore not necessarily less stringent than state command-and-control rules (and could in practice be more stringent), but it is difficult to ascertain exactly what is expected of operators on federal and Indian lands. As a result, it is unclear to us (and perhaps also to operators) whether compliance with a particular state (or tribal) rule is adequate to meet those standards.

66. Forest SERVICE, USDA, WAYNe National Forest Land aNd Resource MaN. AGEMENT PLAN app. $\mathrm{H}$, available at http://www.fs.usda.gov/Internet/FSE_DOCUMENTS/ stelprdb5387924.pdf.

67. Onshore Order No. 2, Drilling Operations, 43 C.F.R. $§ 3160$ (1988).

68. Oil and Gas; Hydraulic Fracturing on Federal and Indian Lands, 78 Fed. Reg. $31,636,31,661$ (proposed May 24, 2013) (to be codified at 43 C.F.R. $\$ 3160$ ).

69. Onshore Order No. 2, Drilling Operations, 43 C.F.R. $§ 3160$ (1988).

70. Id.

71. Richardson et al., supra note 6 , at 33 .

72. Id. at 34 .

73. Id. at 35-38. 
Onshore Order No. 2 was issued in 1988, well before the shale gas development boom. However, new information can alter what BLM determines is adequate to satisfy the performance standards it imposes. This illustrates the flexibility of a performance standard approach.

\section{Casing and Cementing Testing}

BLM requires mechanical integrity tests (MITs) before fracking operations begin and every five years thereafter. ${ }^{74}$ All six of the western states require MITs, and four of them require testing at five-year intervals. ${ }^{75}$

Colorado, Montana, and Wyoming require logging to ensure that casing is properly bound to cement, and New Mexico requires such logging in certain counties. ${ }^{76}$ Colorado and New Mexico, in the counties where logging is required, specifically require CBLs. ${ }^{77}$ Similar to BLM's more general CEL requirement, Wyoming and Montana require CBLs or other "acceptable" or "equivalent" methods. ${ }^{78}$ California and Utah do not require logging. ${ }^{79}$

Wyoming requires logging results as part of its approval-todrill process, and Colorado requires logging results thirty days after the setting of production casing in the form of an "interval report" to ensure compliance with approved drilling plans. ${ }^{80}$ In contrast, BLM would not require CEL results until thirty days after fracking is completed, unless monitoring indicates a problem with the casing. ${ }^{81}$

74. Oil and Gas; Hydraulic Fracturing on Federal and Indian Lands, 78 Fed. Reg. $\S$ 31,636, 31,647 31,653 (proposed May 24, 2013) (to be codified at 43 C.F.R. 3162.3-3(c)(3)(i), 3162.3-3(f)).

75. N.M. CODE R. $\S 19.15 .26 .11$ (LexisNexis 2008); CoLO. CODE REGS. § 404-1:326(a) (2013); MONT. ADMIN. R. 36.22.1416 (2011); 4 WYO. CODE R. § 7(d) (LexisNexis 2008); UTAH ADMIN. CODE R. 649-5-5 (2013); CAL. CODE REGS. tit. 14 § 1724.10(j) (2011).

76. Colo. CODE REGS. § 404-1:317(o) (2013); MONT. ADMIN. R. 36.22.1416(3) (2011); 4 Wyo. CODE R. § 7(f)(iii) (LexisNexis 2010); N.M. CODE R. § 19.15.39.9, 19.15.39.10 (LexisNexis 2008).

77. COLO. CODE Regs. § 404-1:317(o) (2013); N.M. CODE R. § 19.15.39.9, § 19.15.39.10 (LexisNexis 2008). (2011).

78. 4 WYo. Code R. § 7(f)(iii) (LexisNexis 2010); MonT. AdMIN. R. 36.22.14.18(3)

79. Cal. Code Regs. tit. $14 \S 1722$ (2011); UTAH AdMIN. CODE R. 649 (2013).

80. 4 Wyo. CODE R. § 7(f)(iii) (LexisNexis 2010); CoLo. CODE ReGS. \$ 404-1:317(o) (2013); COLO. CODE REGS. § 404-1:308B (2013).

81. Oil and Gas; Hydraulic Fracturing on Federal and Indian Lands, 78 Fed. Reg. $\S$ 31,636, 31,651-52 (proposed May 24, 2013) (to be codified at 43 C.F.R. § 3162.3-3(e)(1), (4)). 


\section{Frack Fluid Disclosure}

As noted above, BLM would require operators to use FracFocus (or an equivalent method) to fulfill the requirement to report frack fluids after completing operations. ${ }^{82}$ Colorado, New Mexico, and Montana also require disclosure after operations take place, ${ }^{83}$ whereas Wyoming requires disclosure beforehand, as part of the approval process. ${ }^{84}$ Colorado and Montana require submission to FracFocus. ${ }^{85}$ California and Utah currently lack disclosure rules. ${ }^{86}$ Given that operators on federal lands will also be subject to state rules, a BLM rule requiring disclosure only after fracking is completed would not affect operators in the four states that require pre-fracking disclosure but would be important in states without any disclosure rules.

All four states with disclosure rules (Colorado, Montana, New Mexico, and Wyoming) and BLM ask for disclosure of chemical names and Chemical Abstracts Service (CAS) numbers, ${ }^{87}$ additive types and the concentration or maximum concentration of each chemical used in the additives, the total concentration or maximum total concentration of each chemical in frack fluids, and the total volume of water or frack fluid used. ${ }^{88}$ Trade secret exemptions are permitted by all four states and BLM. ${ }^{89}$ However, Colorado and Montana mandate that trade secret information be released to healthcare professionals if they sign a confidentiality agreement, or in the case of emergency situations, without the confidentiality agreement. ${ }^{90}$ BLM, New Mexico, and Wyoming do not have such rules.

82. Oil and Gas; Hydraulic Fracturing on Federal and Indian Lands, 78 Fed. Reg. $\S$ 31,636, 31,656 (proposed May 24, 2013) (to be codified at 43 C.F.R. 3162.3-3(i)).

83. Colo. Code REGS. § 404-1:205A(b)(2) (2012); N.M. CODE R. § 19.15.16.19(b) (LexisNexis 2008); MONT. ADMIN. R. 36.22.1015 (2011).

84. 3 WYO. CODE R. $§ 45$ (d) (LexisNexis 2010).

85. COLO. CODE REGS. $§ 404-1: 205 A(b)(2)$ (2012); MONT. ADMIN. R. 36.22.1015 (2011).

86. CAL. CODE REGS. tit. 14 (2011); UTAH ADMIN. CODE R. 649 (2013).

87. CAS numbers are unique numerical identifications assigned by the Chemical $\mathrm{Ab}$ stracts Service to all chemicals described in open scientific literature.

88. Oil and Gas; Hydraulic Fracturing on Federal and Indian Lands, 78 Fed. Reg. $\S$ 31,636, 31,656 (proposed May 24, 2013) (to be codified at 43 C.F.R. 3162.3-3(i)); CoLO. CODE REGS. § 404-1:205A(b)(2) (2012); MoNT. ADMIN. R. § 36.22.1015; N.M. CODE R. § 19.15.16.19 (LexisNexis 2008); 3 WYO. CODE R. $§ 45$ (d) (LexisNexis 2010).

89. Oil and Gas; Hydraulic Fracturing on Federal and Indian Lands, 78 Fed. Reg. § 31,636, 31,659 (proposed May 24, 2013) (to be codified at 43 C.F.R. 3162.3-3(j)); 3 WYo. CODE R. $\S 45(\mathrm{f})$ (LexisNexis 2010); N.M. CODE R. $\S 36.22 .1016$ (LexisNexis 2008); Colo. CODE REgS. § 404-1:205A(b) (2012); MONT. ADMIN. R. § 36.22.1016 (2011). (2011).

90. Colo. Code Regs. § 404-1:205A(b)(5) (2012); MONT. ADMIN. R. $\S 36.22 .1016$ 
BLM declined to revise the rule ${ }^{91}$ to follow several states (in addition to Colorado and Montana) that require limited disclosure of trade secrets under certain circumstances. ${ }^{92}$ BLM claims that the Federal Trade Secrets Act makes it a crime to release trade secret information even under such circumstances. ${ }^{93}$ However, comments submitted in response to BLM's 2012 proposal gave detailed legal explanations of why the act does not prevent disclosure of trade secrets to health professionals, or perhaps at all. ${ }^{94}$ Furthermore, courts have emphasized that the act was not meant to prevent agencies from promulgating rules requiring disclosure, but to "forestall casual or thoughtless divulgence-disclosure made without first going through a deliberative process with an opportunity for input from concerned parties." ${ }^{95}$ BLM authority to require disclosure of trade secrets therefore remains ambiguous.

\section{Wastewater/Fluid Storage}

As explained above, BLM's 2013 and 2012 proposals do not require tanks for storage of any fluids, but they do require the use of (at a minimum) single-lined pits for flowback and other wastewater storage; BLM reserves the discretion to require additional measures to protect against leakage. ${ }^{96}$ BLM rules would not restrict types of fluids that can be stored in pits. Four of the western states also allow lined pit storage for all fluids. ${ }^{97}$ However, New Mexico requires an application to use a pit, which must include operating and maintenance procedures, a closure plan, and a hydrogeological report. ${ }^{98}$ Montana also restricts the type of fluids that can be stored in pits, and many other states restrict the cir-

91. Oil and Gas; Hydraulic Fracturing on Federal and Indian Lands, 78 Fed. Reg. 31,636 (proposed May 24, 2013) (to be codified at 43 C.F.R. $\$ 3160$ ) at 98-99.

92. At least six states (Colorado, Montana, Arkansas, Ohio, Pennsylvania, and Texas) have rules requiring operators to release trade secret information to health professionals. In four of the states (Colorado, Montana, Pennsylvania, and Texas), confidentiality agreements must be signed unless there is an emergency situation, and in the remaining two states (Ohio and Arkansas), confidentiality agreements are not required. See MATTHEW MCFEEley, Natural Res. Def. Council, State Hydraulic Fracturing Disclosure Rules and ENFORCEMENT: A COMPARISON (2012), available at http://nrdc.org/energy/files/FrackingDisclosure-IB.pdf.

93. Oil and Gas; Hydraulic Fracturing on Federal and Indian Lands, 78 Fed. Reg. $31,636,31,660$ (proposed May 24, 2013) (to be codified at 43 C.F.R. $\S 3160$ ).

94. See, e.g., NATURAl Res. Def. COUNCIL, COMMENTS ON PROPOSED RUle ON OIL AND Gas; Well Stimulation, Including Hydraulic Fracturing, on Federal and State LANDS (2012), available at http://sierraclub.org/pressroom/downloads/BLM-comments-9-1012.pdf

95. CNA Fin. Corp. v. Donovan, 830 F.2d 1132, 1141 (D.C. Cir. 1987).

96. Oil and Gas; Hydraulic Fracturing on Federal and Indian Lands, 78 Fed. Reg. 31,636, 31,655-56 (proposed May 24, 2013) (to be codified at 43 C.F.R. $\$ 3162.3-3(\mathrm{~h})$ ).

97. See Richardson et al., supra note 6, at 50-51.

98. N.M. CODE R. § 19.15.17.9(B)(4) (2013). 
cumstances under which pits can be used or the types of fluids they can store. ${ }^{99}$

Comments in response to the 2012 proposal requested BLM to require double-lined pits or tanks for some or all fluids. ${ }^{100}$ In the 2013 proposal, BLM claims that single-lined pits and tanks "reasonably protect land and water" and are in keeping with the American Petroleum Institute's recommended practices for handling completion fluids. ${ }^{101} \mathrm{BLM}$ did, however, request an evaluation on the costs of requiring flowback fluids to be stored in tanks. ${ }^{102}$ Other commenters argued that the fluid storage regulation was repetitious with state rules (a claim generally made regarding the BLM proposal). ${ }^{103}$ But according to BLM, its pit liner requirement would "compel only six additional lined pits per year," because most of the states where BLM manages oil and gas resources already require pit liners. ${ }^{104}$

\section{Wastewater Transportation Tracking}

In choosing not to revise the 2012 proposal to include more information on wastewater transportation plans as requested by some commenters, BLM pointed to Onshore Order No. 7,105 which requires an operator to submit a copy of the disposal facility's permit and, where wastewater will travel over federal or Indian lands off the lease site, a BLM right-of-way authorization. ${ }^{106}$ The proposal leaves out comprehensive record-keeping of wastewater transportation, which many states require. ${ }^{107}$

Colorado, Utah, and New Mexico have record-keeping requirements, and New Mexico also requires a permit for wastewater transportation. ${ }^{108}$ While some aspects that are typically included in record-keeping, such as the location of the disposal facility, are required by Onshore Order No. 7, many other aspects are left out,

99. See, e.g., 225 ILL. COMP. STAT. ANN. 732/1-75 (West 2013) (allowing pits for temporary storage only in the event that flowback is more than anticipated; see also MICH. ADMIN. CODE R. 324.407 (2006) (limiting the type of wastewater that can be stored in pits and requires tanks if drilling is located in a residential zone).

100. Oil and Gas; Hydraulic Fracturing on Federal and Indian Lands, 78 Fed. Reg. $31,636,31,655$ (proposed May 24, 2013) (to be codified at 43 C.F.R. $§ 3160$ ).

101. Id.

102. Id.

103. $I d$.

104. Id. at 31,666

105. Oil and Gas; Hydraulic Fracturing on Federal and Indian Lands, 78 Fed. Reg. 31,636, 51,655-56 (proposed May 24, 2013) (to be codified at 43 C.F.R. $§ 3160$ ). (1993).

106. Onshore Order No. 7, Disposal of Produced Water, Section III.B., 43 C.F.R. $\S 3160$

107. See Richardson et al., supra note 6, at 57-58.

108. See id.; see also UTAH ADMIN. CODE $§ 649-9-11$ (2013) (updated after the RFF study came out). 
including dates of pickup and delivery, the type of fluid being transported, and a requirement to hold on to transportation records for a specified period of time. ${ }^{109}$

However, BLM may have had a good reason for leaving out such record-keeping. Wastewater transportation by means of vehicles using interstate highways is regulated by the Department of Transportation (DOT) ${ }^{110}$ and is outside the jurisdiction of BLM ${ }^{111}$ while drilling occurs on federal lands, transportation may not. While BLM could have created more stringent regulations for tracking wastewater transportation on public lands, jurisdiction would shift to the DOT whenever interstate highways were used. Wastewater transported on state or private roads would fall within the jurisdiction of the state and would also be outside of BLM's jurisdiction.

\section{Accident Reporting}

Existing BLM rules require operators to notify BLM when "undesirable events occur," which may include accidental spills or releases of hydrocarbon fluids, produced water, hydraulic fracturing flowback fluids, or other substances. ${ }^{112}$ Notification is required within twenty-four hours for accidents considered major. ${ }^{113}$ The majority of all states with shale gas development have specific maximum time limits for accident reporting, with California being the only state of the six analyzed here that does not have such requirements. Montana requires reporting immediately, and the remaining four require reporting within twenty-four hours. ${ }^{114}$

109. Onshore Order and Gas Order No. 7, Disposal of Produced Water, 43 C.F.R. $\S$ 3160 (1993).

110. 49 C.F.R. Subt. B, Ch. I (2011).

111. "Equipment and vehicles using interstates and highways must be licensed and follow Department of Transportation procedures for transporting wastewater. These procedures are outside of BLM's jurisdiction." U.S. DEP'T OF THE INTERIOR, BUREAU OF LAND Mgmt., Reference No. 3100/(UT-922000), Protest to the InClusion of Certain ParCels in the February 19, 2013 Competitive OIL and Gas Lease Sale (Feb. 15, 2013) available at http://www.blm.gov/pgdata/etc/medialib/blm/ut/lands_and_minerals/oil_and_ gas/february_20130.Par.41810.File.dat/Living\%20Rivers\%20Protest\%200213\%202-15-13\% 20508.pdf.

112. U.S. DeP'T OF THE InTERIOR, Geological SuRvey Conservation Div., NTL-3A, Notice to LESSEES AND OPERATORS OF ONSHORE FEDERAL AND INDIAN OIL AND GAS LEASES, REPORTING OF UNDESIRABLE EVENTS, available at http://blm.gov/pgdata/etc/medialib/ blm/wo/MINERALS_REALTY_AND_RESOURCE_PROTECTION_/energy/oil_and_gas.Pa r.86049. File.dat/N'LL3A.pdf.

113. Id.

114. See Richardson et al., supra note 6, at 71-72 


\section{Well Idle and Temporary Abandonment}

Most states, including all six western states analyzed, put specific time restrictions on how long a well can be left idle until it must be put back into operation, converted to a waste disposal well, plugged and abandoned, or in many states, temporarily abandoned. ${ }^{115}$ These regulations prevent operators from allowing wells to fall into disrepair. BLM did not address idle time or temporary abandonment in its 2013 or 2012 proposals, nor are these addressed in Onshore Order No. 2. Well idle time and time limits vary widely across states. Four of the western states (Colorado, New Mexico, Utah, and Wyoming) allow temporary abandonment, during which an operator may continue to leave a well idle but must generally take certain measures to reduce the risk of damage or contamination. ${ }^{116}$

\section{Overall Comparisons}

The simplest comparison of existing state and proposed BLM rules is a tally of the regulatory elements we analyze for the states and BLM. This gives some sense of the breadth of BLM's regulatory posture compared with state regulations. Figure 1 shows the total number of elements regulated by California, Colorado, Montana, New Mexico, Utah, Wyoming, and BLM. Of the elements in our analysis, Colorado and New Mexico regulate all eleven in some fashion. Under its 2013 proposal and existing rules, BLM would regulate seven elements. Only California among the six states analyzed would regulate fewer.

Table 1 shows each element and how it is regulated by each state, existing BLM regulations, and the 2013 proposal, including the regulatory tool used. This shows two notable differences between BLM rules and the state rules, which were also explained in more detail above. First, BLM neither has nor proposes to add requirements for idle time or temporary abandonment, which are regulated in some way by all six states. Second, all six states have command-and-control regulations addressing various aspects of casing and cementing, whereas BLM has performance standards.

The table also shows that existing BLM rules do not appear to impose significant substantive requirements on operators in these states, at least for the elements in our analysis-though, as noted, determining the effective stringency of BLM casing and cementing 
performance standards is difficult. State command-and-control rules for casing and cementing could be stringent enough to satisfy BLM performance standards for casing and cementing. Since, like BLM, four of the states require accident reporting within twentyfour hours and a fifth requires reporting immediately, BLM regulation impacts operators in only one of the six states we considered-California, where accident reporting is not required.

BLM's 2013 proposed rule is more stringent than the rules in certain states in only three areas, also shown in Table 1. First, BLM rules would ensure that pit liners are to be used on federal and Indian lands in the three states that do not already require them generally. Second, the BLM rule would add frack fluid disclosure requirements on federal and Indian lands in both California and Utah. Finally, a BLM rule would require operators to record integrity tests in CELs on federal and Indian lands in California, Utah, and Montana, and it would require more frequent tests (MITs) in California and Utah.

Figure 1. Number of Regulated Elements

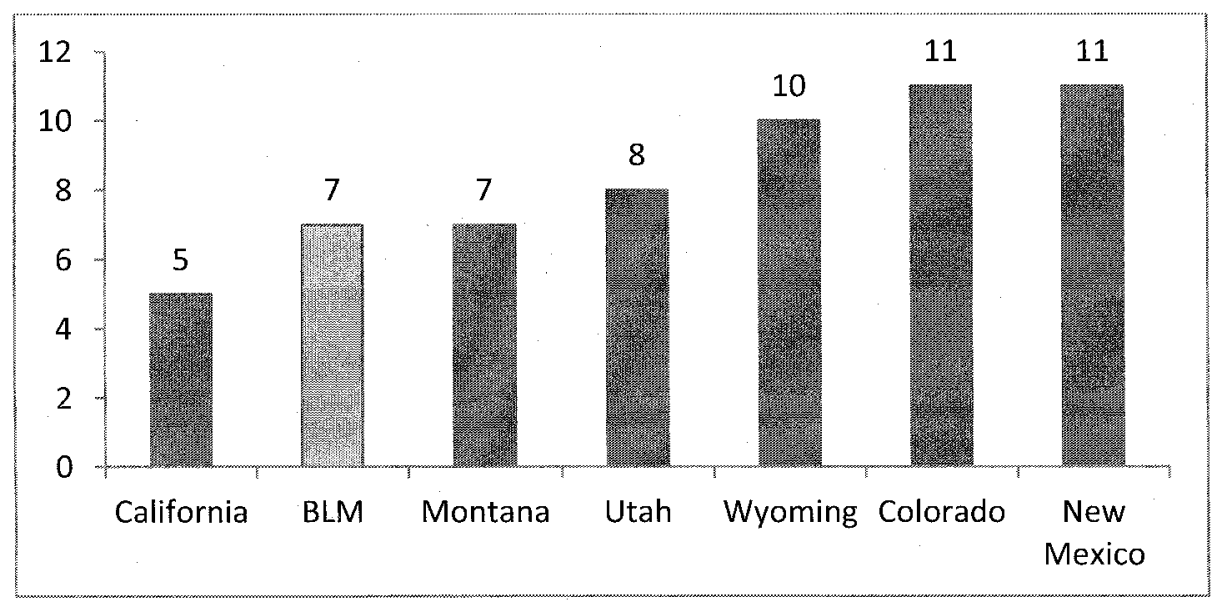




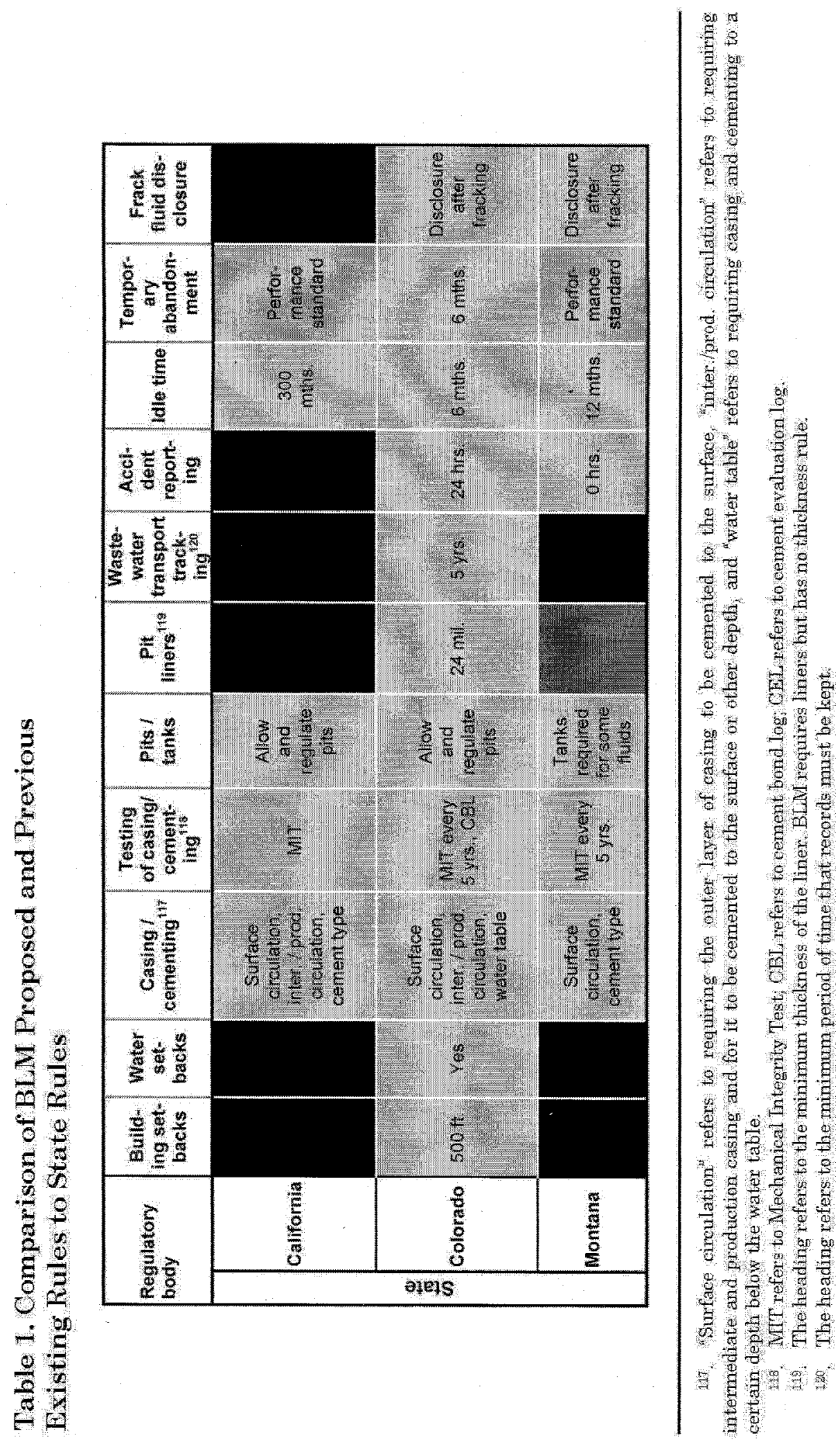




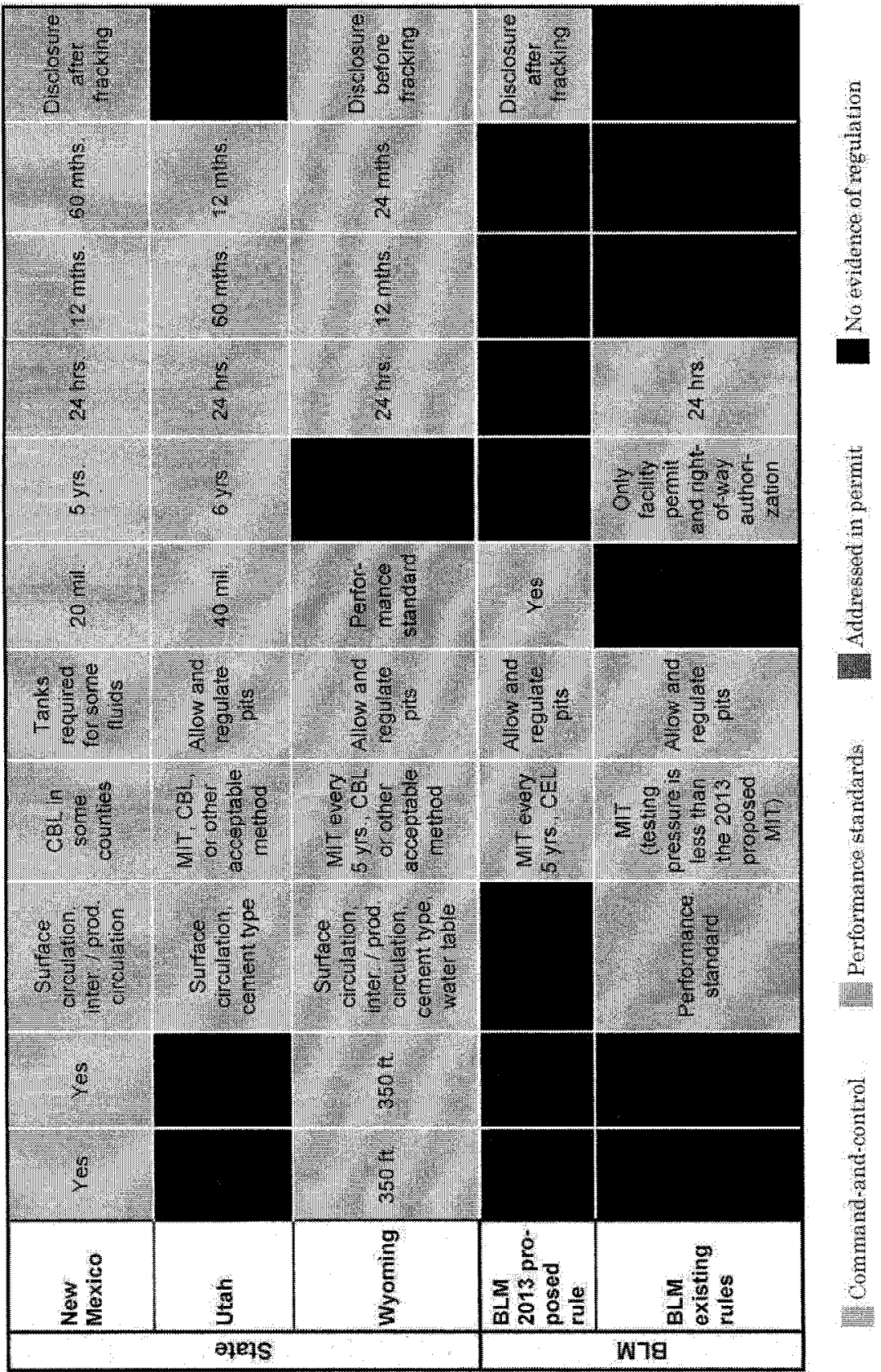




\section{CONCLUSIONS}

The federal government controls access to oil and gas resources on thirty-six million acres of federal and Indian lands (and private lands for which the federal government retains subsurface rights) across twenty-four states. This makes BLM, as administrator and steward of these lands, the largest single player in unconventional development and, in effect, the largest regulator. With its 2012 and 2013 proposals, BLM set out to update rules not revised in decades to better address risks imposed by the rapid expansion in unconventional development driven by hydraulic fracturing and horizontal drilling technologies.

Whether BLM achieved that goal remains a subject of debate. The 2013 proposed rule contains significant changes that generally make the rule less restrictive than the 2012 proposal. In some cases, lack of BLM authority means that the breadth of the rule appears limited in comparison with state rules. For a crucial part of the development process - casing and cementing-BLM's rules are not updated at all, though existing rules are framed as performance standards that appear sufficiently flexible to address any additional risks imposed by unconventional development.

Comparing BLM's proposal with existing state rules reveals that in a few states and regulatory areas, operators would face additional requirements on federal lands. For example, BLM rules would require use of lined pits and disclosure of frack fluids in those states that do not impose similar requirements. Generally, however, BLM rules do not appear to impose significant requirements beyond existing state regulations, at least across the regulatory elements we analyzed and in those states with large federal landholdings. Moreover, in some regulatory areas (notably setback requirements), states generally have requirements whereas BLM does not.

Nevertheless, it is important to remember that, like the states, BLM may place additional requirements on operators during the permitting process as a condition of approval. And like a landowner, it might also add lease terms that go beyond the requirements in the regulations. Moreover, BLM might enforce its regulations more (or less) consistently or effectively than states do.

Critics of BLM's proposal have claimed that it either is inadequate to protect the public and the environment on federal lands or is unnecessary and burdensome. Given the background of state regulation, a better measure may be whether each component of the proposal provides meaningful additional protections. Based on our analysis, BLM's proposal does fill some apparent gaps in state 
regulation but does not significantly deviate from the prevailing set of requirements under state law.

Indeed, industry critics allege that BLM's proposal unnecessarily duplicates state rules. Unless BLM imposes costly new procedural requirements, there is little downside to such federal rules that duplicate state rules for the most part and impose additional requirements only in states that leave certain practices unregulated. BLM's resources therefore are probably best focused on those areas either where some states have failed to regulate a risk that BLM considers significant or where the consequences of development are greater on public lands. Advocates of stronger regulation thus would be better off advocating for such things as greater requirements for flowback/wastewater containment so as to better protect pristine surface waters, rather than criticizing BLM's decision not to include setback restrictions from buildings, which state law may already address adequately. Generally, BLM appears to be following this model.

Alternatively, however, some argue that federal rules should not merely fill gaps in state regulations or address special risks, but rather serve as a model for strong, effective regulations. If one holds this view, than a comprehensive, internally consistent set of regulations is important. Limitations on BLM's jurisdiction, resources, and expertise make this task difficult, however. 
